\title{
The disturbance-driven changes of periphytic algal communities in a Danubian floodplain lake
}

\author{
T. Žuna Pfeiffer ${ }^{(1)}$, M. Mihaljević(1),^, D. Špoljarić(1), F. Stević(1), \\ A. Plenković-Moraj(2)
}

Received September 4, 2014

Revised December 3, 2014

Accepted December 3, 2014

Key-words: periphyton, algae, artificial substrata, disturbance, floodplain

\section{ABSTRACT}

Disturbance event-driven changes in periphytic algal communities were studied in a Danubian floodplain using artificial substrata (glass slides). The hydrological regime of the river-floodplain system strongly influenced the physical and chemical environment of the investigated lake. Directional changes in the algal communities, demonstrated by the results of non-metric multidimensional scaling, indicated three distinct phases in periphyton development. Strong seasonal influences in the initial accrual phase favored diatom dominance in spring and rapid development of a community composed of filamentous and stalk-forming chlorophytes towards "climax" in summer. Macrophyte and metaphyton stands spreading represented a physical constraint for periphytic algal development. Irrespective of periphyton age and structure, the onset of disturbances resulted in an immediate decrease in periphytic biomass. Disturbances deeply transformed algal communities, whereas the morpho-functional properties of algal species were found to be decisive in community adaptations to altered environmental conditions. Tightly attached and stalk forming diatoms were shown to have an ability to resist and quickly recover from physical disturbance. Our results highlight the necessity for further development of the morpho-functional classification of periphytic algae, which will contribute to more precise evaluations of disturbancedriven events in freshwater ecosystems.

\section{RÉSUMÉ}

Les changements des communautés d'algues périphytiques induits par les perturbations dans un lac de la plaine inondable du Danube Mots-clés:
périphyton,
algues,
substrats
artificiels,
perturbation,
plaine inondable

\begin{abstract}
Des modifications provoquées par les événements perturbants dans les communautés d'algues périphytiques ont été étudiés dans une plaine inondable du Danube en utilisant des substrats artificiels (lames de verre). Le régime hydrologique du système rivière-plaine inondable influence fortement l'environnement physique et chimique du lac étudié. Les changements de trajectoire dans les communautés d'algues, démontrés par les résultats d'analyse multidimensionnelle non métrique, ont indiqué trois phases distinctes dans le développement du périphyton. De fortes influences saisonnières dans la phase initiale d'implantation favorisent la domination de diatomées au printemps et le développement rapide d'une communauté composée de filamenteuses et de chlorophytes à tige vers un "climax"
\end{abstract}

(1) Josip Juraj Strossmayer University of Osijek, Department of Biology, Cara Hadrijana 8/A, HR-31000 Osijek, Croatia

(2) University of Zagreb, Faculty of Science, Department of Biology, Rooseveltov trg 6, HR-10000 Zagreb, Croatia

* Corresponding author: mmihaljevic@biologija.unios.hr 
en été. Le développement des macrophytes et des métaphytes représente une contrainte physique pour le développement d'algues périphytiques. Indépendamment de l'âge du périphyton et de sa structure, l'apparition de perturbations a entraîné une diminution immédiate de la biomasse périphytique. Les perturbations ont transformé profondément les communautés d'algues, alors que les propriétés morpho-fonctionnelles des espèces d'algues sont décisives dans les adaptations de la communauté aux conditions environnementales altérées. Les diatomées étroitement attachées et formant des manchons ont une capacité de résister et de se remettre de la perturbation physique rapidement. Nos résultats mettent en évidence la nécessité du développement ultérieur d'une classification morphofonctionnelle des algues périphytiques, ce qui contribuera à des évaluations plus précises des événements perturbants dans les écosystèmes d'eau douce.

\section{INTRODUCTION}

Periphytic algal communities are receiving increasing attention in light of environmental changes in freshwater ecosystems. The high biodiversity within the limited space they inhabit, and their fast growth rate and short life cycle allow them to quickly respond to environmental alternations. Accordingly, periphytic algae are widely used as bioindicator organisms in the European Water Framework Directive (2000).

Numerous investigations of periphyton development in various freshwater systems allow for a generalized synthesis which states that periphytic algae growth processes show a similar pattern of short-term biomass accrual (see Azim and Asaeda 2005 for review). Periphyton biomass initially increases exponentially through colonization and growth, subsequently reaching its peak. The driving variables in this "accrual phase", which control species membership and promote biomass development, include nutrients, space, and light. Then, a shift towards the dominance of loss processes through death, emigration, sloughing, and grazing follows. The duration of each phase depends on the seasonal variations in the ecological variables, particularly in the variability of available nutrient concentrations, physical factors (water temperature, light intensity), and the abundance of grazers (Larned, 2010). However, certain events, which are more or less predictable, may affect the development of periphyton by removing or disrupting communities, and thus creating an opportunity for new individuals to become dominant. These environmental changes represent a disturbance for periphyton development. Therefore, physical disturbances (e.g. substrate movement, rapid changes in hydraulic forces, heat, light) being mere episodes, can remove organisms at rates faster than the rates of accrual or recruitment (Stanley et al., 2010).

Numerous investigations have been conducted in order to elucidate periphyton responses to disturbances, focusing on the resistance and resilience of lotic algal communities (Peterson and Stevenson, 1992). A particularly prominent one was a habitat matrix conceptual model for stream periphyton defined by Biggs et al. (1998). The core of this model is a classification of periphyton taxa according to the specific adherence strategies and ability to acclimate to the disturbance and nutrient resource supply. R-selected (ruderal) taxa have small-sized cells and are rapid colonists adapted to disturbed habitats with variable enrichment. C-selected (competitive) taxa have an upright growth form and thus compete most effectively for nutrients and light while S-selected (stress-tolerant) taxa have a high stature and nitrogen-fixing capacity that allows them to tolerate oligotrophic conditions.

Focusing on sediment diatoms, ecological guild concept defined by Passy (2007) becomes very used for the assessment of disturbance gradients in running waters. Despite of its apparent simplicity-grouping of diatom taxa in only three ecological guilds (low profile, high profile and motile), many recent studies (e.g. Rimet and Bouchez, 2011, 2012; Stenger-Kovács et al., 2013) showed that guild approach is strong enough to be good indicator of environmental changes. 


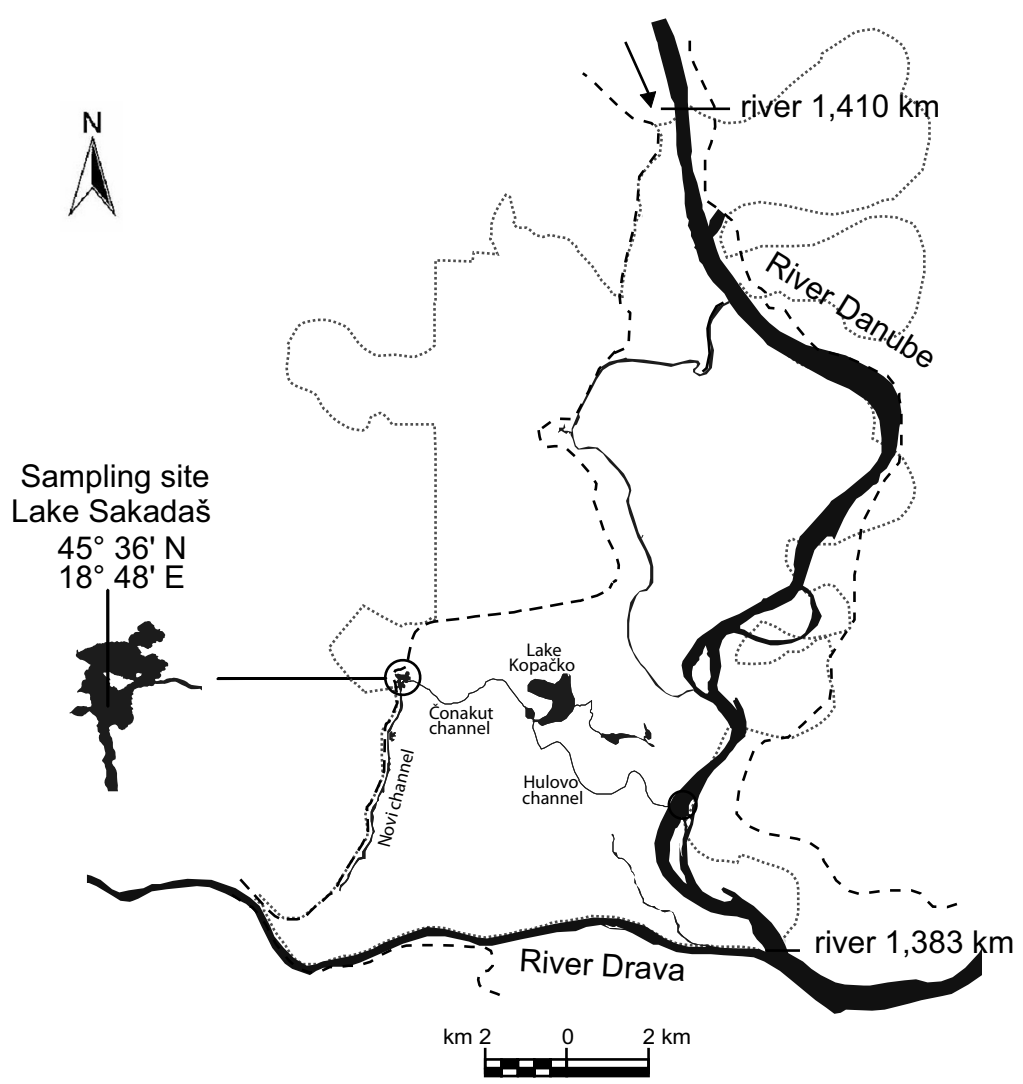

\section{Figure 1}

Study area - Lake Sakadaš, a part of the Danubian floodplain area. Dotted grey line marks the border of Nature Park Kopački Rit; dashed black line represents the embankment of the rivers Danube and Drava; arrow indicate the river flow.

Riverine floodplains are recognized as the most dynamic ecosystems, where the flood pulse, varying in timing, magnitude, and frequency, can be seen as the principal driving force in rearranging the physical environment of habitats along the floodplain gradient and consequently affects (more or less) every level of biological organization in their structure and dynamics (Tockner and Stanford, 2002). Despite the fact that periphyton is a prominent feature of wetlands and other floodplain habitats (Gottlieb et al., 2006; Murakami et al., 2009; Mihaljević and Žuna Pfeiffer, 2012), scientific knowledge on the growth dynamics, sensitivity to disturbances, as well as recovery of periphytic algal communities in floodplain habitats still lags far behind that of the periphyton in lotic habitats. The overall objective of our study was to examine temporal variations in the structure and dynamics of periphytic algal communities in a floodplain lake which is part of a large natural floodplain of the Danube River. Since high flooding events in spring and summer became frequent in the Middle Danube in the last decade, hydrologically induced changes of the lake environment could be expected. We presumed that physical disturbances will occur and significantly modify the structure of periphytic algal communities irrespective of their growth stage.

\section{MATERIAL AND METHODS}

\section{> STUDY SITE}

The floodplain area of the Danube River between the kilometer points 1383 and 1410 (covers approximately $180 \mathrm{~km}^{2}$ ) is internationally recognized as a Ramsar site and at the national level it is a protected area of Kopački Rit Nature Park (Croatia, Figure 1). The area is a part of 
the Pannonian biogeographic region and has a typical continental climate. Permanent water habitats, such as shallow lakes, river side arms and natural channels, have a significant role in the hydrology of the floodplain. The intensity of floodplain inundation primarily depends on the hydrological regime of the Danube. Minor floods (3.0-3.5 m Danube water level at the gauge station at river $1401 \mathrm{~km}$ ) inundate only the nethermost terrain, while extremely high floods (Danube water level more than $5 \mathrm{~m}$ ) inundate almost the whole floodplain area (Schwarz, 2005). Spatial gradient of the abiotic environment homogenization appeared during total flooding of the area (Mihaljević et al., 2014).

The investigated Lake Sakadaš is located in the western part of the floodplain, close to the embankment which delineates the inundation area. Through a system of natural channels (total length ca. $10 \mathrm{~km}$ ) it is in hydrological connection with the main river channel. The lake has an average depth of ca. $5 \mathrm{~m}$, with a surface water area of about $0.15 \mathrm{~km}^{2}$. The lake is in eutrophic/hypertrophic state, but fluctuations of phytoplankton biomass are in strong relation with the flooding intensity. Thus, the lake can switch repeatedly back and forth between phytoplankton-clear conditions to phytoplankton-turbid conditions with habitual appearances of cyanobacterial (Planktothrix, Limnothrix, Cylindrospermopsis) blooms (Mihaljević and Stević, 2011). The lake shore is overgrown with Phragmites sp., adjoined by floodplain forest of white willows (Salix alba L.). The sampling location for periphyton study was chosen in one unshaded bay in the eastern part of the lake, ca. $10 \mathrm{~m}$ away from the lake shore.

\section{> FIELD STUDY SETUP AND SAMPLING}

Artificial substrates, glass slides $(6 \times 14 \mathrm{~cm}$; at a distance of $20 \mathrm{~cm})$ were oriented vertically (the longer side was parallel to the bottom of the lake), fastened to a wooden frame and placed at a depth of $20 \mathrm{~cm}$ beneath the water surface, allowing to ensure the optimal light availability to the surface of the substratum (Weitzel, 1979). Since the water level of the floodplain lake fluctuates, the wooden frames were elevated above the water surface using sunken buoys and fastened with rope to stone blocks bedded in the lake bottom. The rope was long enough to enable the holder to freely slide vertically. In that way, the glass slides maintained the same position in the water column during the study.

Field studies were conducted in two study series - the first series was exposed in April, while the second series was exposed in July and both series were incubated until December 2010. The slides were sampled randomly every 2 weeks. During each sampling event, 3 replicates were taken of each series, placed in a glass bottle of sterile water and analyzed separately. In total, 57 replicates were taken from the first series, and 36 from the second series. Periphyton from each glass slide was scraped (using razor blade), split into 3 parts and used to determine: (i) chlorophyll concentrations (Chla and Chlc), (ii) periphyton biomass - dry weight (DW), (iii) qualitative and quantitative algal compositions. Water samples for chemical analysis were taken simultaneously with the periphyton samples at the depth of $20 \mathrm{~cm}$. Water temperature (WT), $\mathrm{pH}$, dissolved oxygen concentration (DO), and conductivity (Cond) were measured in situ using portable instrument WTW Multi 340i (Wissenschaftlich-Technische Werkstätten, Weilheim, Germany). Transparency was measured using a Secchi disc. Lake water depth (WD) was measured with a weighted rope. Daily Danube water level data were obtained for the gauge station at river $1401.4 \mathrm{~km}$.

\section{> SAMPLE ANALYSIS}

Water chemical variables, nitrates $\left(\mathrm{NO}_{3}^{-}\right)$, nitrites $\left(\mathrm{NO}_{2}^{-}\right)$, ammonium $\left(\mathrm{NH}_{4}^{+}\right)$, total nitrogen $(\mathrm{TN})$, and total phosphorus (TP), as well as periphyton biomass (DW) were analyzed according to APHA (1992). Chlorophyll concentrations were estimated according to UNESCO (1966) and Strickland and Parsons (1968). Chlorophyll a corrected for phaeopigments was measured before and after acidification and calculated according to Lorenzen (1967). Algal taxa were 
identified with a light microscope (Carl Zeiss Jena) at multiple magnifications using standard literature for species determination: Huber-Pestalozzi, 1962; Hustedt, 1976; Hindak et al., 1978; Anagnostidis and Komárek, 1985, 1988; Komárek and Anagnostidis, 1989. The algal nomenclature was updated according to AlgaeBase website (Guiry and Guiry, 2012).

For quantitative analyses, individuals of each species (filament or colony was considered to be equal to one individual) were counted on a millimetre grid with an area of $1 \mathrm{~cm}^{2}$ (Stilinović and Plenković-Moraj, 1995). Only diatom taxa were counted as a group. For detailed diatom identification, samples were cleaned in distilled water, $\mathrm{H}_{2} \mathrm{O}_{2}$ and $\mathrm{HCl}$ treated, washed and embedded in Canada balsam. In each sample, 300-400 valves were counted. The total number of each diatom species was calculated as the ratio between the number of diatom valves counted in samples embedded in Canada balsam and the total number of diatoms counted on a millimeter grid. Since the periphyton was scraped from glass slides into a certain volume of tap water, it was taken into account in the final conversion of the abundance of each species per unit area (ind. $\cdot \mathrm{cm}^{-2}$ ). Dominant species were estimated from percentage contribution of individual species to total abundance. Only those species that had a minimum of $5 \%$ contribution to total abundance were considered to be dominants.

\section{> STATISTICAL ANALYSIS}

Pearson's correlation coefficient was used to analyze the correlation between environmental variables. Calculations were performed using Statistica 7.0 (StatSoft, Inc.). Non-metric multidimensional scaling (NMDS) based on log-transformed $(\log (x+1))$ algal abundance data and Bray-Curtis similarity was used to explain the similarity in periphytic algal communities between sampling days in each study series separately. To investigate the differences between the series regarding the periphyton growth phases (accrual/loss), periphyton biomass (DW), chlorophyll concentrations, algal abundance, species richness and diversity were tested by analysis of similarity (ANOSIM test). Both NMDS and ANOSIM were performed using the statistical program PRIMER version 5.0 (Clarke and Warwick, 2001). A multivariate ordination method was assessed to analyze the relationship between the environmental variables and abundance of dominant algal species using software CANOCO 4.5. Redundancy Analysis (RDA) was performed because the initial Detrended Correspondence Analysis (DCA) suggested that a linear method was appropriate since the gradient length of species did not exceed three standard deviations (Lepš and Šmilauer, 2003). Algal abundance data and environmental variables were log- transformed before analysis. Species diversity was calculated according to Shannon and Weaver (1949).

\section{RESULTS}

\section{> ENVIRONMENTAL CHARACTERIZATION}

According to the Danube water level fluctuations (Figure 2), frequent flood pulses with different intensity and duration occurred almost throughout spring and summer, whereas the appearance of extremely high flood pulse in July inundated the whole floodplain area. Afterwards, a long period without flooding set in from the end of October until December when the short-term high flood pulse inundated again almost the entire floodplain area.

Significant changes in the hydrological regime strongly influenced the physical and chemical environment of the investigated lake (Figure 3). The water depth varied between $4.83 \mathrm{~m}$ and $11.67 \mathrm{~m}$. Seasonal oscillations in water temperature ranged from $1.0^{\circ} \mathrm{C}$ to $25.0^{\circ} \mathrm{C}$. Transparency oscillated in the range of $0.80-2.70 \mathrm{~m}$ whereas lower values were found during flooding conditions and were closely associated with Chla concentrations in the water column $(r=-0.71, p<0.01)$. Interestingly, peak Chla values were recorded at the beginning of periphyton colonization, first in April $\left(56.50 \mu \mathrm{g} \cdot \mathrm{L}^{-1}\right)$ and then in July $\left(55.34 \mu \mathrm{g} \cdot \mathrm{L}^{-1}\right)$. Although conductivity was highly variable (363-929 $\left.\mu \mathrm{S} \cdot \mathrm{cm}^{-1}\right)$, higher values were recorded in 


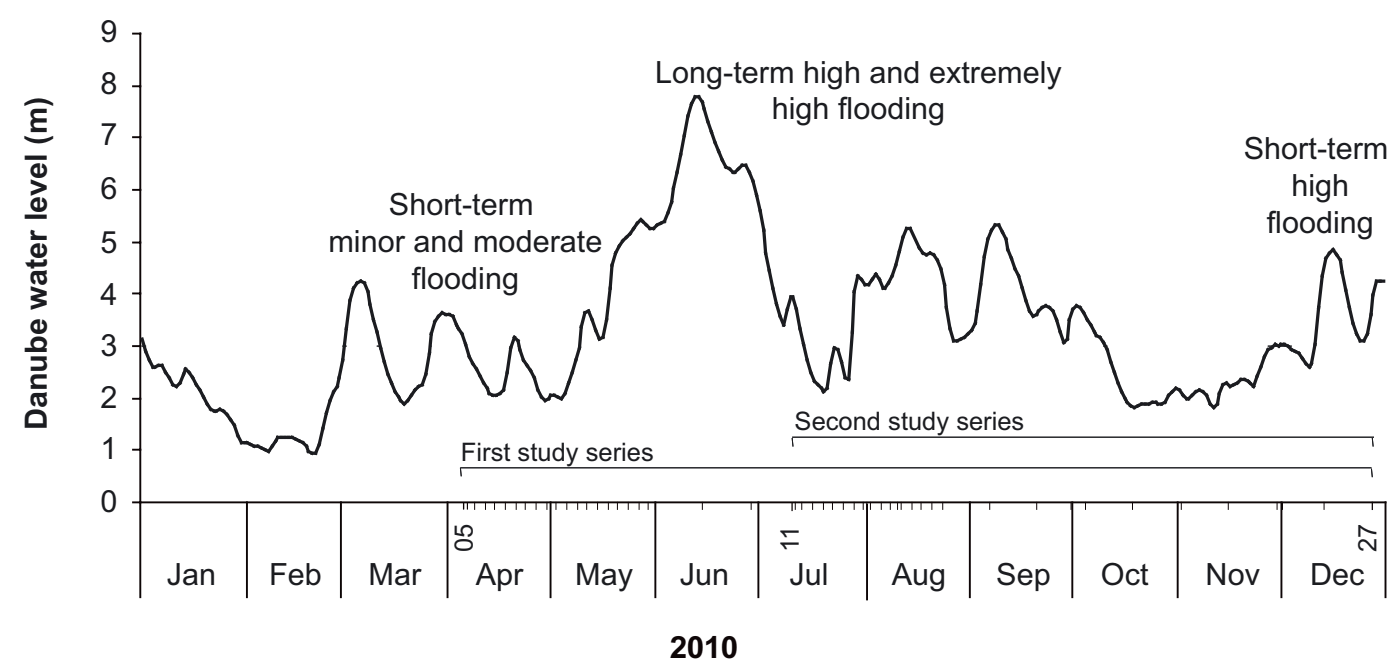

\section{Figure 2}

Annual courses of the Danube water level at the river $1401 \mathrm{~km}$ in 2010. Note: flooding categorization according to the Danube water level - minor $(3.0 \leqslant 3.5 \mathrm{~m})$, moderate $(>3.5 \leqslant 4.0 \mathrm{~m})$, major $(>4.0 \leqslant$ $5.0 \mathrm{~m})$ and extremely high $(>5.0 \mathrm{~m})$.
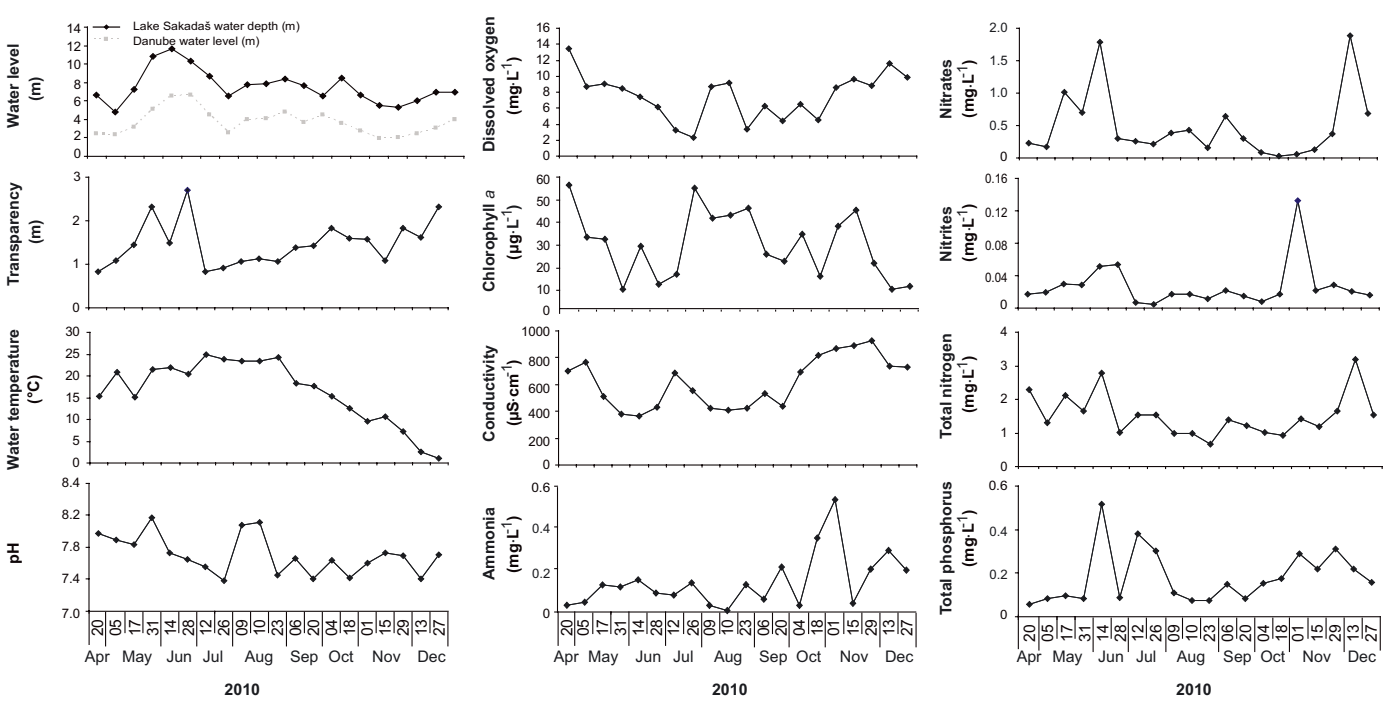

Figure 3

Variations of the limnological variables in the floodplain lake during the study period (April-December, 2010).

the period without flooding. Significant negative correlation was found between conductivity and Danube water levels $(r=-0.77, p<0.01)$. Low DO concentrations $\left(2.34-3.19 \mathrm{mg} \cdot \mathrm{L}^{-1}\right)$ were registered in July during the short-term cessation of summer floods. The $\mathrm{pH}$ values, always above 7 , indicated alkaline conditions. In general, nutrient concentrations were high ( $0.18 \mathrm{mg} \cdot \mathrm{L}^{-1}$ mean value of TP, $1.52 \mathrm{mg} \cdot \mathrm{L}^{-1}$ mean value of TN) with peak values of TP in spring and TN in autumn. Very high $\mathrm{NH}_{4}^{+}$concentration $\left(0.54 \mathrm{mg} \cdot \mathrm{L}^{-1}\right)$ was found in autumn after the long-lasting floods.

After extremely high flooding in June, mass-developed submerged and floating macrophytes (Ceratophyllum demersum L., Salvinia natans (L.) All., Hydrocharis morsus ranae L.) and metaphyton stands mainly comprising of filamentous green algae (Cladophora sp., Mougeotia sp., Oedogonium sp.), inhabited by cyanobacteria, small green algae and diatoms were spread throughout the lake till the mid-October (Figure 9). 

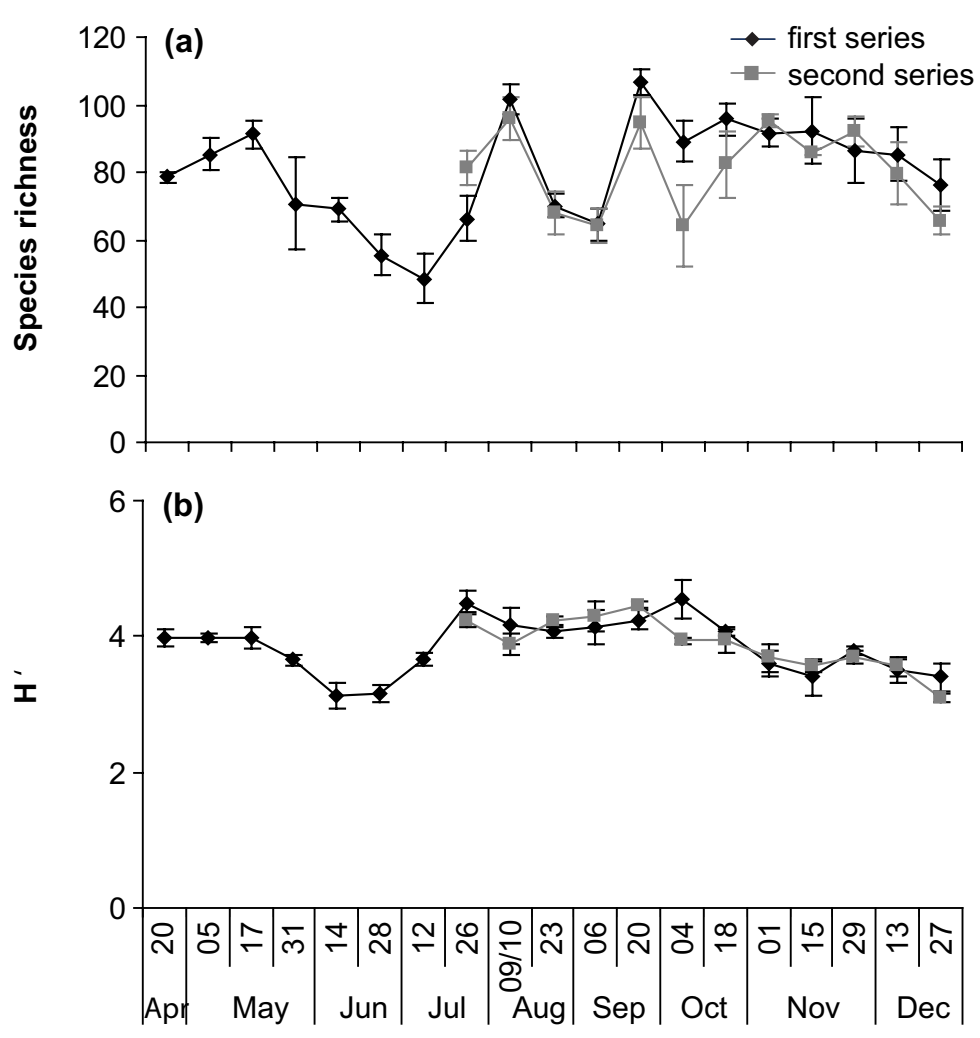

2010

\section{Figure 4}

Changes in the number of algal taxa (a), and Shannon-Weaver ( $\left.H^{\prime}\right)$ diversity index (b) in first and second series during the study period in 2010. Bars represent standard deviations $(n=3)$.

\section{> SUCCESSIONS OF PERIPHYTIC ALGAL COMMUNITIES}

A total of 259 periphyton taxa were identified in the first series among which 18 taxa were dominant as well as 214 taxa in the second series among which 14 taxa were dominant (Figures 4 and 5). The Shannon-Weaver $\left(\mathrm{H}^{\prime}\right)$ similarity index (Figure 4) indicated high biodiversity.

The NMDS revealed 4 distinctive groups in the first series and 3 groups in the second series (Figure 6). Group I represents the initial periphytic accrual phase in both series, lasting from April to May in the first series and July-August in the second series. This phase was characterized by a gradual increase of periphytic biomass (DW), chlorophyll concentrations, and algal abundance (Figure 7). The periphytic community in the first series was characterized by diatoms among which Encyonema ventricosum, Ulnaria ulna, U. acus, and Gomphonema spp. were dominant in April, followed by an over-dominance of Achnanthidium minutissimum. However, the periphytic community in the second series was characterized by the well-developed filamentous (Oedogonium sp.) and stalk forming green algae (Characium ornithocephalum), together with Xanthophyceae (Characiopsis spp.) accompanied by diatoms. Group II represents the periphyton loss phase (in the first series that lasted from June to October, in the second series from August to October), which was characterized by low periphytic biomass, low chlorophyll concentrations, and very low algal abundance. The most significant was a predominance of diatoms with contributions of up to $90 \%$ to the total algal abundance. A. minutissimum over-dominated (more than $70 \%$ of the total algal abundance) in the first series until mid-July (group Ila). Later, periphytic communities became very similar in both series with dominance of G. parvulum, A. minutissimum, Epithemia adnata, and Halamphora veneta. Group III represents the second accrual phase in both series, which lasted from October to December. This new accrual phase was characterized by a gradual increase in periphytic 

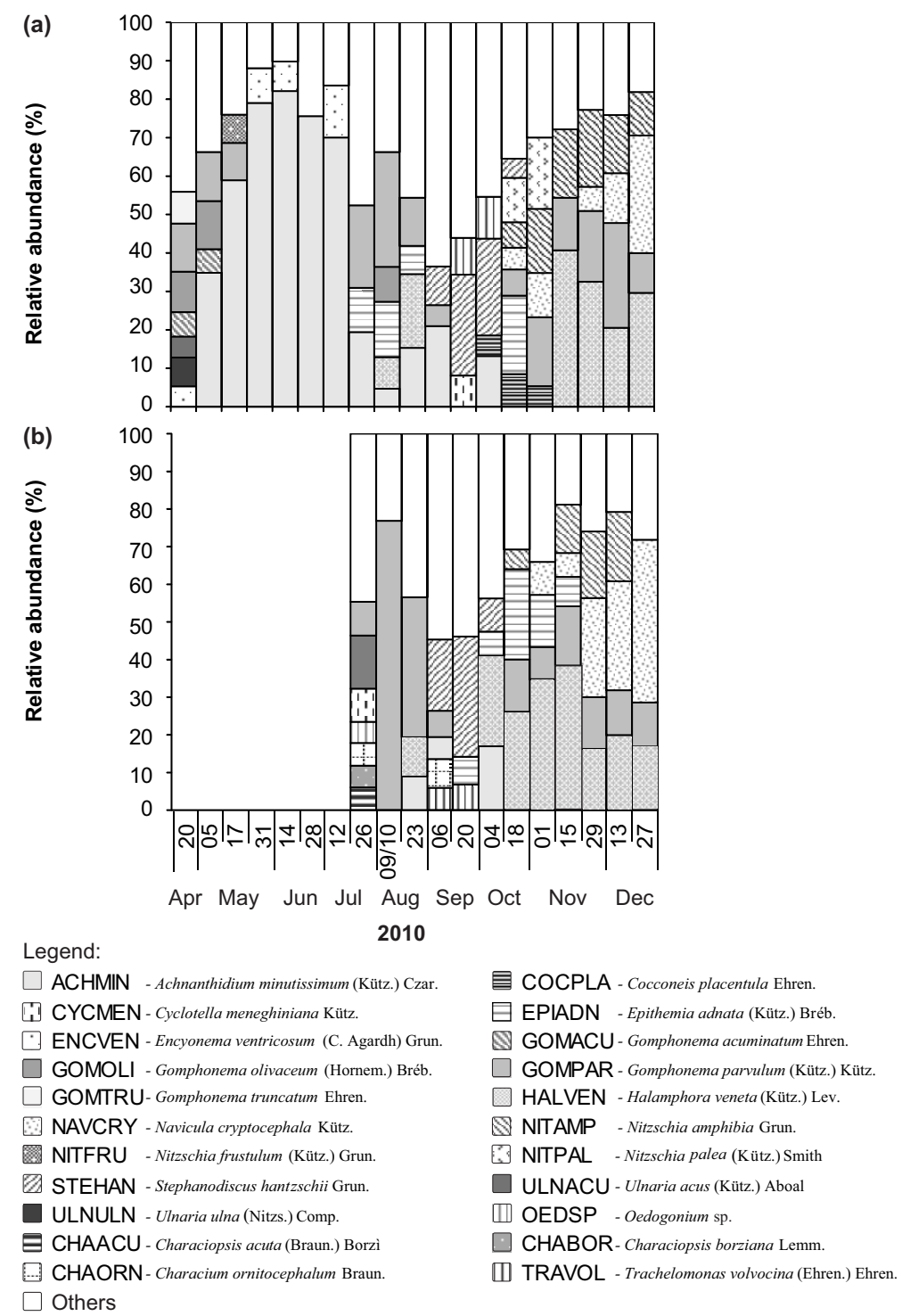

\section{Figure 5}

Changes in the relative abundance of dominant periphyton algal species in first (a) and second (b) study series. Bars represent standard deviations $(n=3)$.

biomass, chlorophyll concentrations, and a high abundance of diatoms (up to $99.55 \%$ of the total abundance) among which G. parvulum, Nitzschia amphibia, H. veneta, and Navicula cryptocephala were dominant. According to ANOSIM, no significant differences in DW, Chla, Chlc concentrations, species richness, diversity, and algal abundance were found between the periphytic initial accrual phases $(p>0.05)$, as well as between loss phases $(p>0.05)$ in both series. During the second accrual phases, Chlc $(R=0.30, p=0.01)$ and total algal abundance $(R=0.46, p=0.002$ ) were significantly higher in the first series.

RDA was performed on the environmental and species data set, for each study series separately (Figure 8). The two main axes of RDA explained $90.5 \%$ of total variance (axis 1: $66.5 \%$, axis 2: $24 \%$ ) and indicated a significant relationship between environmental variables and periphytic algal abundance data in the first series (Figure 8a). Most of the variance contained in the first RDA axis was explained by the water temperature $\left(r_{\mathrm{RDA} 1}=-0.75, p<0.05\right)$, conductivity $\left(r_{\mathrm{RDA} 1}=+0.66, p<0.05\right)$, and $\mathrm{NH}_{4}^{+}\left(r_{\mathrm{RDA} 1}=+0.57, p<0.05\right)$. In the second axis, most of the variance was accounted for by the $\mathrm{pH}\left(r_{\mathrm{RDA} 2}=-0.63, p<0.05\right)$. Species H. veneta, N. amphibia, E. adnata, N. cryptocephala, Cocconeis placentula, and 

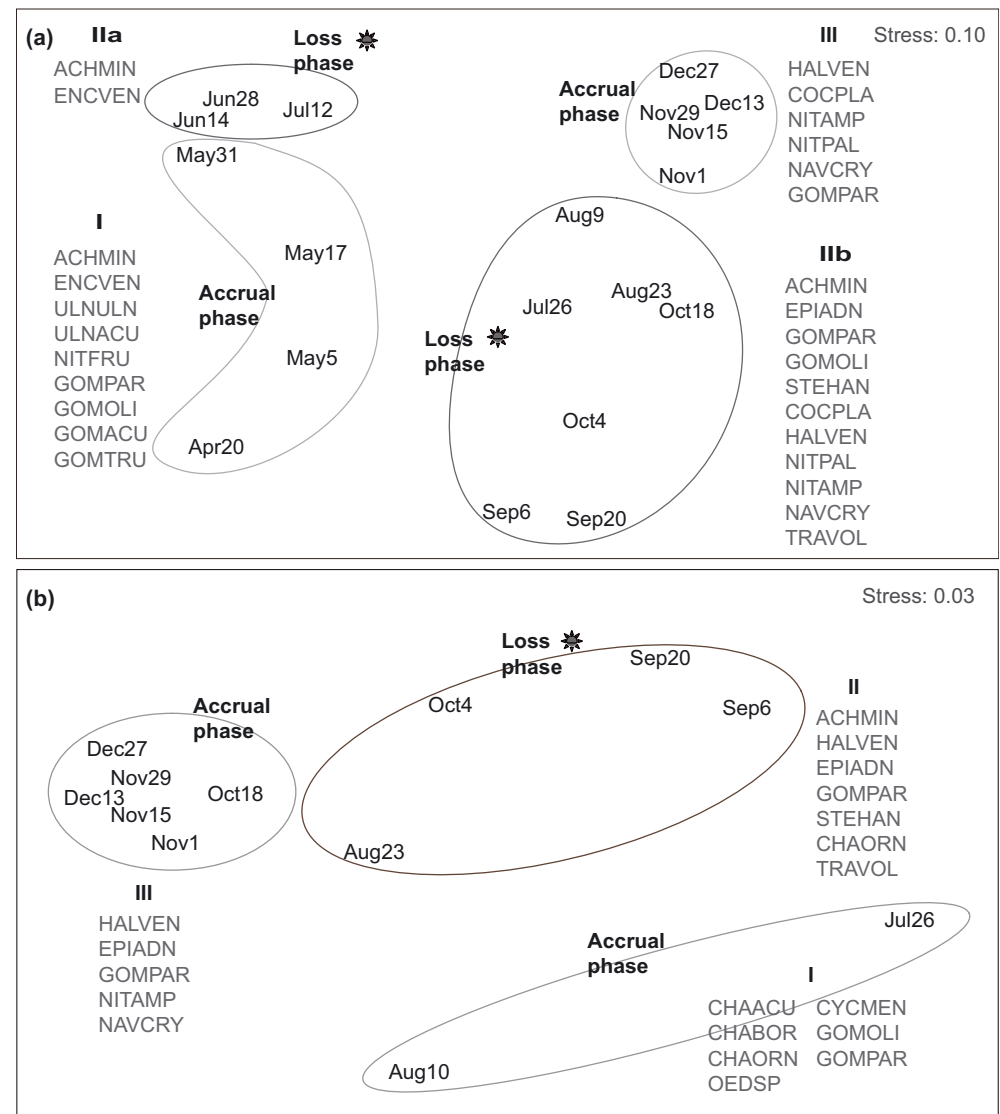

Legend:

绎 Metaphyton and macrophytes appearance

\section{Figure 6}

Non-metric multidimensional scaling (NMDS) based on algal abundance data in first series (a), and second series (b) in 2010. See Figure 5 for species code.
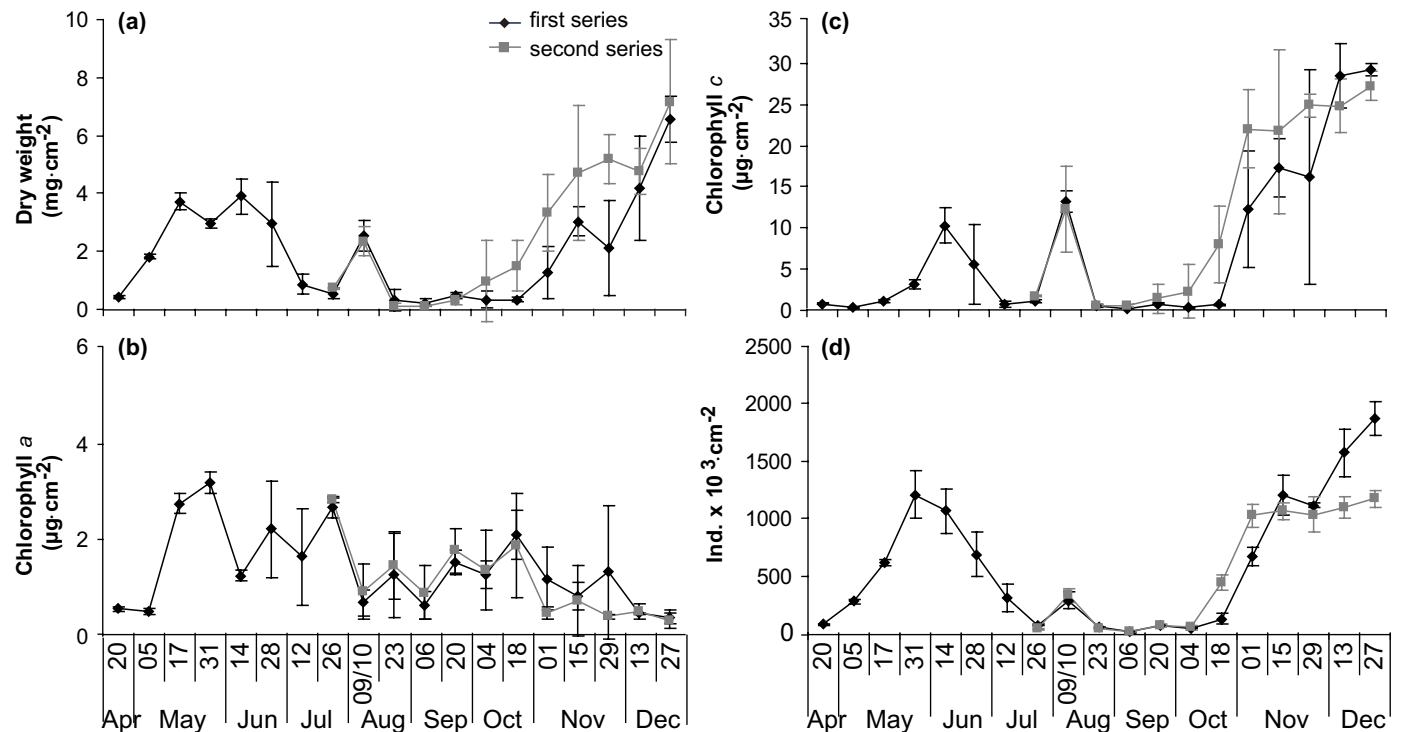

2010

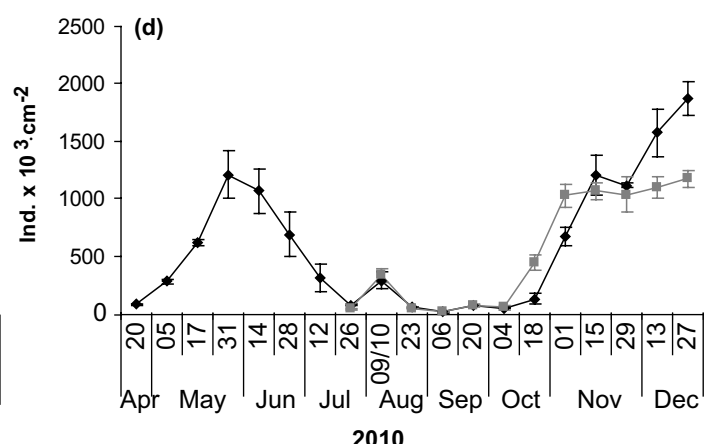

Figure 7

Temporal variations of periphyton dry-weight (a), chlorophyll a (b) and chlorophyll c (c) concentrations and algal abundance (d) in first and second series during the study period in 2010. Bars represent standard deviations $(n=3)$. 

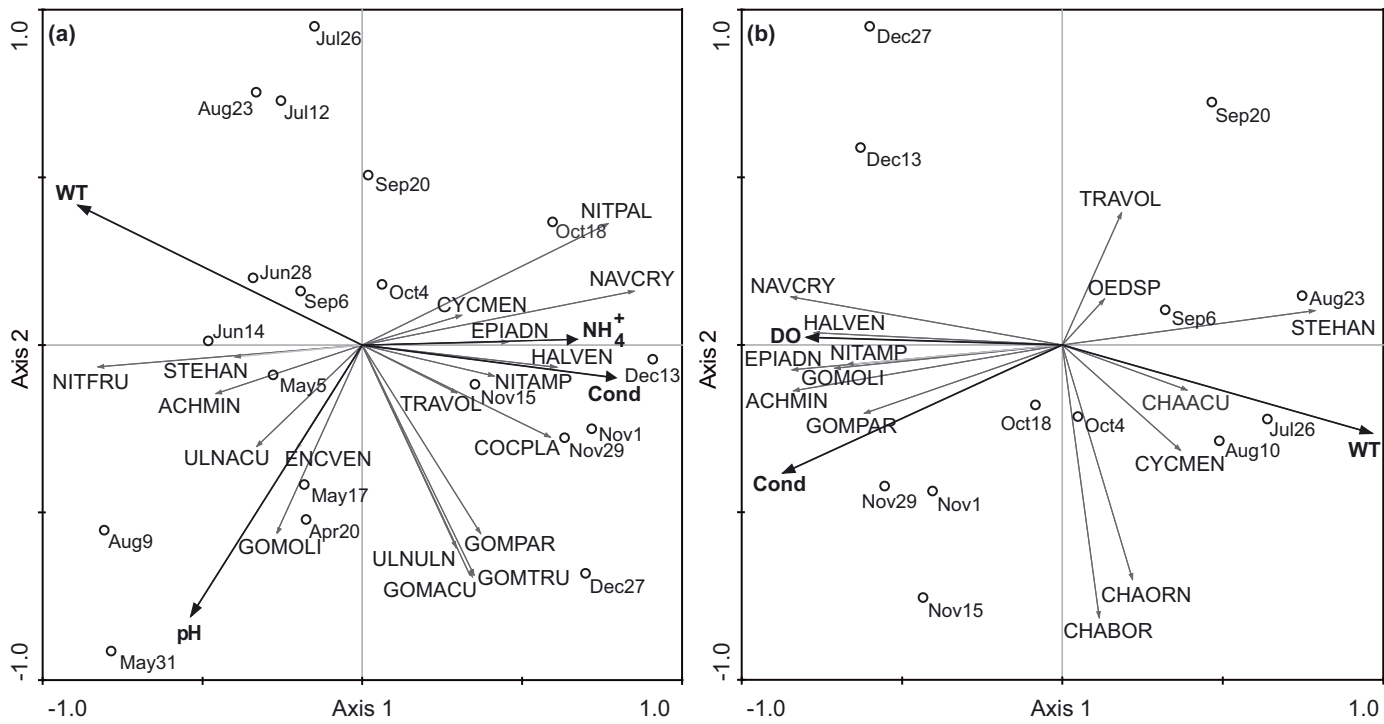

Figure 8

Redundancy analysis (RDA) of periphytic algal abundance data of the first (a) and second (b) study series in 2010. The plot shows the scores of dominant algal species (solid grey arrows) and sampling dates (open circles) along the first and second axes in relation to the statistically significant environmental variables (solid black arrows).

Trachelomonas volvocina reached high abundance in autumn and their development was associated with high conductivity and high $\mathrm{NH}_{4}^{+}$concentration. In the second series, the two main RDA axes accounted for $89.2 \%$ of the total variance (axis $1: 68.3 \%$, axis $2: 20.9 \%$ ) and indicated a significant relationship between environmental variables and periphytic algal abundance data (Figure 8b). Most of the variance contained in the first RDA axis can be explained by the water temperature $\left(r_{\mathrm{RDA} 1}=+0.87, p<0.05\right)$, while conductivity $\left(r_{\mathrm{RDA} 2}=-0.33\right.$, $p<0.05)$ explained most of the variance in the second RDA axis. C. acuta reached high abundance in summer and was associated with higher water temperatures. G. parvulum closely correlated with high conductivity values.

\section{DISCUSSION}

Hydrological conditions, i.e. flooding promoted extensive physical and chemical environmental changes of the floodplain lake. A dilution effect of the riverine water on nutrients and phytoplankton in the lake (Mihaljević et al., 2009) was expressed as an increase in transparency during the flooding. After the floods, the increase of nutrient concentrations and conductivity in the lake appeared due to the natural input and accumulation of organic matter.

Periphyton accrual began in the conditions of short-time (ca. 10 days) lake isolation from the income of floodwaters, but continued to increase in conditions of flooding, both in spring and summer series, indicating that periphytic communities were left undisturbed. However, a strong seasonal influence on periphyton development was evident, as shown by the RDA. Low water temperature in spring can be found as a driving factor favoring the development of diatoms. The community increased in complexity as a result of a gradual development of stalk-forming species (Gomphonema, Encyonema), with a tendency towards vertical overgrowth when Achnanthidium minutissimum become over-dominant due to its capability to change adhesion mode and lift to upper layers adhering to long gelatinous stalks instead of short ones (Ács et al., 2000). Increasing light availability and high water temperature in summer encouraged the growth of filamentous chlorophytes (Oedogonium sp.). Their colonization and growth rates are usually slow in comparison to diatoms, so they appear in older periphytic communities (Biggs et al., 1998). In our case, its rapid colonization could have been 

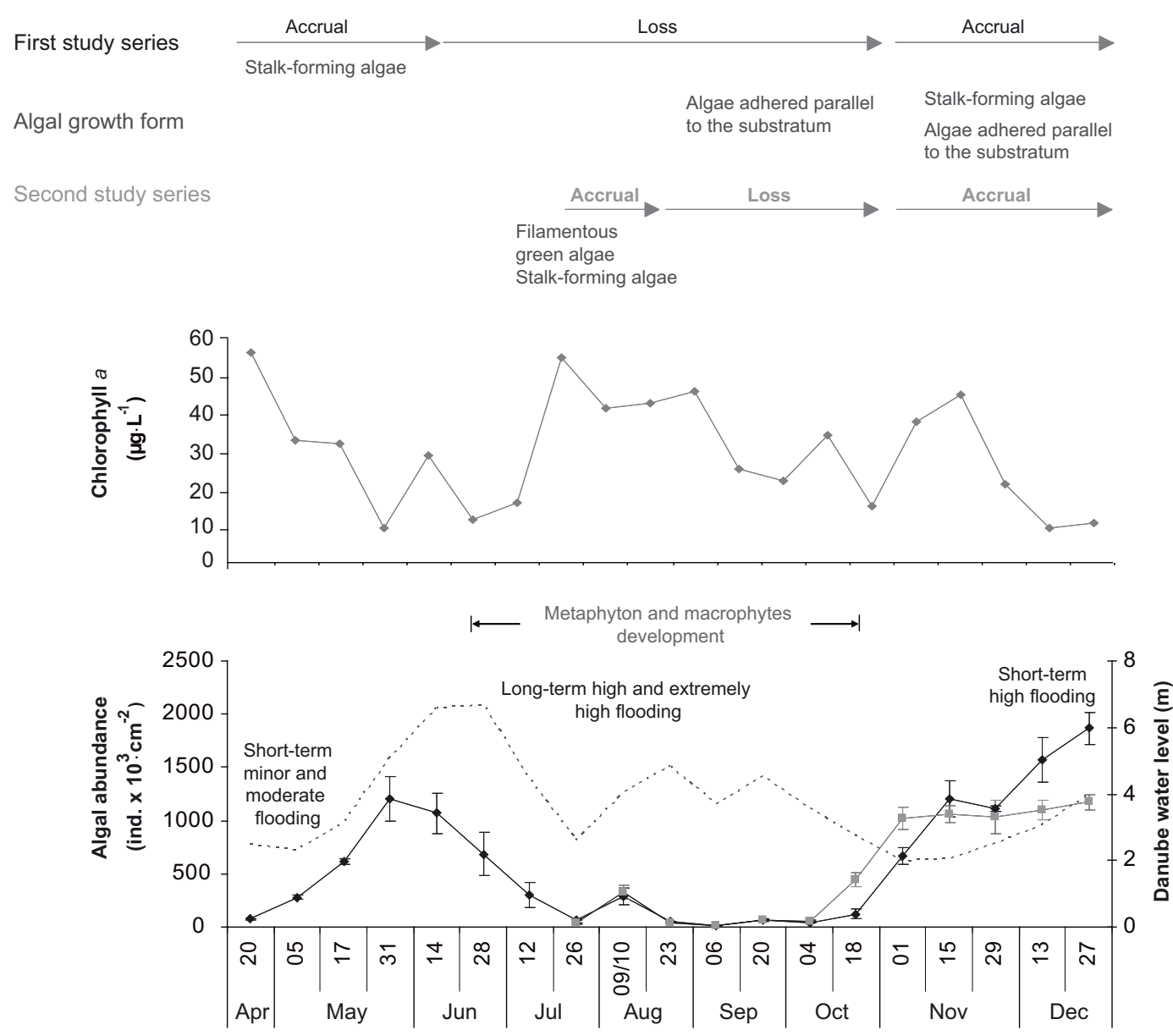

Legend:

2010

- First study series

_- Second study series

Danube water level $(\mathrm{m})$

Figure 9

Synthesis diagram of limnological conditions and periphytic growth phases during 2010 in Lake Sakadaš.

associated with hydrological perturbations. Oedogonium often starts to grow attached to firm substrates such as plants (Albay and Akçaalan, 2008), while in conditions of water mixing, its long filaments become vulnerable to removal (Borges and Necchi Jr., 2008). Altogether, an increase of C-S strategist (Oedogonium) abundance in summer and high periphytic Chla concentrations indicated a more rapid development of the periphyton towards a "climax" community compared to assemblage developed in spring conditions where R-strategists (Achnanthidium, Gomphonema) were dominant.

An abrupt decrease of periphytic biomass and algal abundance occurred immediately after the macrophyte and metaphyton stands spread in the vicinity of the study sites suggesting that a disturbance had appeared (Žuna Pfeiffer et al., 2013). It is known that periphytic biomass loss is rarely a linear function of disturbance intensity or duration because most of the biomass loss occurs immediately after the threshold is exceeded (summarized by Larned, 2010).

Rapid decrease of light caused by shading of floating aquatic plant beds represents the physical constraint for algal development and consequently can have a strong negative effect on periphyton development (e.g. Giorgi et al., 2005; Ferreiro et al., 2013). This is particularly expressed in the wetland microhabitats where periphyton development can be totally 
suppressed during the periods of massive development of floating macrophyte (McCormick et al., 1998). Beside light limitation, the movements of submerged macrophytes swept away large parts of periphyton (visual observation), which could have contributed to the cumulative effects of physical disturbance. Floating mats offered favorable conditions for different aquatic invertebrates (Rotatoria, Oligochaeta, Nematoda, Insecta larve, snails), fishes and other aquatic predators (Vidaković, unpublished data) and high grazing pressure could be expected.

The disturbance acted as a reset mechanism and reverted the algal communities to an early stage of succession. Irrespective of periphyton age and structure, algal communities were rearranged by changing their composition from sensitive species to more tolerant species to cope with the environmentally altered conditions. Diatoms with high immigration and reproductive rates (R-strategists) became dominant (A. minutissimum), accompanied by diatoms adapted to low-light condition (Gomphonema spp., Cocconeis placentula). The disturbance tolerance of $A$. minutissimum, one of the most frequently occurring species in various freshwater ecosystems is widely recognized. Stenger-Kovács et al. (2006) emphasized that it typically reaches higher dominance in streams after flood periods and therefore indicates natural disturbances. Shadow-adapted species such as Cocconeis and Gomphonema were reported as the most competitive among periphytic algae within harsh circumstances (e.g. light limitation) and were found to be well-developed in low-light environment in tropical wetlands (Dunck et al., 2013) and also under duckweed mats (Buczkó and Rajczy, 2001). Generally, tightly attached adnate/prostrate life forms live in the periphyton understory layer which enables them to avoid the shear stress and resist scour (Stevenson, 1996) and thus are found to be highly resistant forms in disturbed environments (Schneck and Melo, 2012).

The rapid increase in periphytic biomass and algal abundance, recorded after the decay of metaphyton and macrophytes in autumn, indicated periphyton recovery and new accrual phase, simultaneously occurring in both series. The re-colonization and regrowth from persistent cells are recognized pathways of periphyton recovery after cessation of disturbances (Branco et al., 2005). The faster increase in algal abundance compared with the initial accrual phase in both study series stresses the importance of a retained biomatrix on the substrates. At the same time, the denuded substrates were suitable for new colonizers, as evidenced by the high algal diversity. Given that microalgal growth is influenced by algal densities on the substrata, it is likely that the reductions in cell density increased the supply of nutrients and light to both persistent cells and new immigrants, thereby stimulating reproduction in a subset of populations (Peterson and Stevenson, 1992). The significant increase of the vertically positioned Nitzschia amphibia and the stalk-forming diatoms (G. parvulum and N. cryptocephala) contributed to a progressive development into a complex three-dimensional community. Beside the ability to move horizontally on a substrate via gliding, characteristic for the most benthic diatoms with raphes, the Nitzschia taxa show aptitude for moving upward through the substrates (Pan et al., 2012).

In spite of the low water temperature, algal abundance reached its highest value for both study series at the end of the field study in December. It is well known that periphytic algae and macrophytes are in competition for nutrients (van Donk and van de Bund, 2002), so the significant increase in nutrient content after macrophyte decay during the lake isolation was favorable for periphyton growth. The highest periphytic algal density found in winter confirmed that temperature need not be a limiting factor when other factors are favorable (Moresco and Rodrigues, 2010) and open "windows of ecological opportunity" for the accrual of periphytic algae can be expected (Tockner et al., 2010).

\section{CONCLUSION}

In pulsed ecosystems such as the investigated riverine floodplain lake, variations of limnological conditions can have a significant role in changing ecological opportunities for algal communities. Our results have shown that, irrespective of periphyton age and structure, the onset of disturbances resulted in an immediate decrease in periphytic biomass. Disturbances 
thoroughly transformed algal communities, whereas the morpho-functional properties of algal species were found to be decisive in community adaptations to altered environmental conditions.

\section{ACKNOWLEDGEMENTS}

This study was supported by the Croatian Ministry of Science, Education and Sports, research project No. 285-0000000-2674. We are grateful to project leader Prof. Jasna Vidaković for her support. We are grateful to Makso Herman for improving the English version of the manuscript. We also wish to thank the Handling Editor and anonymous reviewers for their constructive comments and helpful suggestions which substantially improved this manuscript.

\section{REFERENCES}

Ács E., Kiss K.T., Szabó K. and Makk J., 2000. Short-term colonization sequence of periphyton on glass slides in a large river River Danube, near Budapest. Arch. Hydrobiol. Suppl. 136, Algol. Stud., 100, 135-156.

Albay M. and Akçaalan R., 2008. Effects of water quality and hydrologic drivers on periphyton colonization on Sparganium erectum in two Turkish lakes with different mixing regimes. Environ. Monit. Assess., 146, 171-181.

Anagnostidis K. and Komárek J., 1985. Modern approach to the classification system ofcyanophytes. 1. Introduction. Algol. Stud. Arch. Hydrobiol. Suppl., 71, 291-302.

Anagnostidis K. and Komárek J., 1988. Modern approach to the classification system of cyanophytes. 3. Oscillatoriales. Algol. Stud. Arch. Hydrobiol. Suppl., 80, 327-472.

APHA (American Public Health Association), 1992. Standard Methods for the Examination of Water and Wastewater. American Public Health Association, Washington, DC.

Azim M.E. and Asaeda T., 2005. Periphyton: structure, diversity and colonization. In: Azim M.E., Verdegem M.C.J., van Dam A.A. and Beveridge M.C.M. (eds.), Periphyton: ecology, exploitation and management. CABI Publishing, Wallingford, UK, 15-33.

Biggs B.J.F., Stevenson R.J. and Lowe R.L., 1998. A habitat matrix conceptual model for stream periphyton. Arch. Hydrobiol., 143, 21-56.

Borges F.R. and Necchi Jr. O., 2008. Short-term successional dynamics of a macroalgal community in a stream from northwestern São Paulo State, Brazil. Acta Bot. Bras., 22, 453-463.

Branco C.C.Z., Branco L.H.Z., Moura M.O. and Bertusso F.R., 2005. The succession dynamics of a macroalgal community after a flood disturbance in a tropical stream from São Paulo State, southeastern Brazil. Revista. Brasil. Bot., 28, 267-275.

Buczkó K. and Rajczy M., 2001. Changes of attached diatoms in a dead arm of the Danube between 1992-1999 at Ásványráró (Szigetköz section). Studia Bot. Hung., 32, 39-61.

Clarke K.R. and Warwick R.M., 2001. Change in marine communities: An approach to statistical analysis and interpretation, 2nd ed. PRIMER-E, Plymouth.

Dunck B., Nogueira I.S. and Felisberto S.A., 2013. Distribution of periphytic algae in wetlands (Palm swamps, Cerrado), Brazil. Braz. J. Biol., 73, 331-346.

European Water Framework Directive 2000: Directive 2000/60/EC of the European Parliament and of the Council of 23 October 2000 Establishing a Framework for Community Action in the Field of Water Policy. EN Official Journal of the European Communities L327, http://eur-lex.europa.eu, 72.

Ferreiro N., Giorgi A. and Feijoó C., 2013. Effects of macrophyte architecture and leaf shape complexity on structural parameters of the epiphytic algal community in a Pampean stream. Aquat. Ecol., 47, 389-401.

Giorgi A., Feijoó C. and Tell G., 2005. Primary producers in a Pampean stream: temporal variation and structuring role. Biodivers. Conserv., 14, 1699-1718.

Gottlieb A.D., Richards J.H. and Gaiser E.E., 2006. Comparative study of periphyton community structure in long and short-hydroperiod Everglades marshes. Hydrobiologia, 569, 195-207. 
Guiry M.D. and Guiry G.M., 2012. AlgaeBase. World-wide electronic publication, National University of Ireland, Galway. http://www.algaebase.org; searched on October, 2012.

Hindak F., Cyrus Z., Marvan P., Javornicky P., Komárek J., Etll H., Rosa K., Sladečkova A., Popovsky J., Punčocharova M. and Lhotsky O., 1978. Slatkovodne riasy. Slovenske pedagogicke nakladelstvo, Bratislava.

Huber-Pestalozzi G., 1962. Das Phytoplankton des Süßwassers. Systematik und Biologie. Teil. 2. E. Schweizerbart'śche Verlagsbuchhandlung (Erwin Nägele), Stuttgart.

Hustedt F., 1976. Bacillariophyta. Otto Koeltz Science Publishers, Koenigstein

Komárek J. and Anagnostidis K., 1989. Modern approach to the classification system of cyanophytes. 4. Nostocales. Algol. Stud. Arch. Hydrobiol. Suppl., 56, 247-345.

Larned S.T., 2010. A prospectus for periphyton: recent and future ecological research. J. N. Am. Benthol. Soc., 29, 182-206.

Lepš J. and Šmilauer P., 2003. Multivariate Analysis of Ecological Data Using CANOCO. Cambridge University Press, New York.

Lorenzen C.J., 1967. Determination of chlorophyll and phaeo-pigments spectrophotometric equations. In: Dykyová D. (ed.), Metody studia ecosystémù, Academia Praha, Praha, 336.

McCormick P.V., Shuford III R.B.E., Backus J.G. and Kennedy W.C., 1998. Spatial and seasonal patterns of periphyton biomass and productivity in the northern Everglades, Florida, USA. Hydrobiologia, 362, 185-208.

Mihaljević M. and Stević F., 2011. Cyanobacterial blooms in a temperate river-floodplain ecosystem: the importance of hydrological extremes. Aquat. Ecol., 45, 335-349.

Mihaljević M. and Žuna Pfeiffer T., 2012. Colonization of periphyton algae in a temperate floodplain lake under a fluctuating spring hydrological regime. Fundam. Appl. Limnol., 180, 13-25.

Mihaljević M., Stević F., Horvatić J. and Hackenberger Kutuzović B., 2009. Dual impact of the flood pulses on the phytoplankton assemblages in a Danubian floodplain lake (Kopački Rit Nature Park, Croatia). Hydrobiologia, 618, 77-88.

Mihaljević M., Stević F., Špoljarić D. and Žuna Pfeiffer T., 2014. Spatial pattern of phytoplankton based on the morphology-based functional approach along a river-floodplain gradient. River Res. Appl., DOI: 10.1002/rra.2739.

Moresco C. and Rodrigues L., 2010. Structure and dynamics of the periphytic algae community of Iraí reservoir, Paraná State, Brazil. Acta Sci. Biol. Sci., 32, 23-30.

Murakami E.A., Bicudo D.C. and Rodrigues L., 2009. Periphytic algae of the Garças Lake, Upper Paraná River floodplain: comparing the years 1994 and 2004. Braz. J. Biol., 69, 459-468.

Pan Y., Hughes R.M., Herlihy A.T. and Kaufmann P.R., 2012. Non-wadeable river bioassessment: spatial variation of benthic diatom assemblages in Pacific Northwest rivers, USA. Hydrobiologia, 684, 241-260.

Passy S.I., 2007. Diatom ecological guilds display distinct and predictable behavior along nutrient and disturbance gradients in running waters. Aquat. Bot. 86, 171-178.

Peterson G.C. and Stevenson R.J., 1992. Resistance and resilience of lotic algal communities: importance of disturbance timing and current. Ecology, 73, 1445-1461.

Rimet F. and Bouchez A., 2011. Use of diatom life-forms and ecological guilds to assess pesticide contamination in rivers: Lotic mesocosm approaches. Ecol. Indic., 11, 489-499.

Rimet F. and Bouchez A., 2012. Life-forms, cell-sizes and ecological guilds of diatoms in European rivers. Knowl. Managt. Aquatic Ecosyst., 406, 01.

Schneck F. and Melo A.S., 2012. Hydrological disturbance intensity overrides substrate roughness effects on the resistance and resilience of stream benthic algae. Freshw. Biol., 57, 1678-1688.

Schwarz U., 2005. Landschaftsökologische Charakterisierung des Kopački Rit unter besonderer Berücksichtigung von Flusslandschaftsformen sowie deren Genese und Typologie. Dissertation. University of Wien.

Shannon C.E. and Weaver W., 1949. The Mathematical Theory of Communication. University Illionis Press, Urbana, USA, 117.

Stanley E.H., Powers S.M. and Lottig N.R., 2010. The evolving legacy of disturbance in stream ecology: concepts, contributions, and coming challenges. J. N. Am. Benthol. Soc., 29, 67-83. 
Stenger-Kovács C., Padisák J. and Bíró P., 2006. Temporal variability of Achnanthidium minutissimum (Kützing) Czarnecki and its relationship to chemical and hydrological features of the Tornastream, Hungary. 6th International Symposium on Use of algae for monitoring rivers. Hungary, Balatonfüred, 133-138.

Stenger-Kovács C., Lengyel E., Crossetti L.O., Üvegesa V. and Padisák J., 2013. Diatom ecological guilds as indicators of temporally changing stressors and disturbances in the small Torna-stream, Hungary. Ecol. Indic., 24, 138-147.

Stevenson R.J., 1996. An introduction to algal ecology in freshwater benthic habitats. In: Stevenson R.J., Bothwell M.L. and Lowe R.L. (eds.), Algal ecology, freshwater benthic ecosystems, Academic Press, San Diego, 3-33.

Stilinović B. and Plenković-Moraj A., 1995. Bacterial and phytoplanktonic research of Ponikve artificial lake on the island of Krk. Period. Biol., 97, 351-358.

Strickland J.D.H. and Parsons T.R., 1968. A practical hand-book of seawater analysis. Bull. Fish. Res. Board Can., 167, 1-310.

Tockner K. and Stanford J.A., 2002. Riverine floodplains: present state and future trends. Environ. Conserv., 29, 308-330.

Tockner K., Pusch M., Borchardt D. and Lorang M.S., 2010. Multiple stressors in coupled river-floodplain ecosystems. Freshw. Biol., 55, 135-151.

UNESCO, 1966. Determinations of photosynthetic pigments in seawater. Report of SCOR - UNESCO Working Group 17. Monographs on Oceanographic Methodology, Paris, 69.

van Donk E. and. van de Bund W.J., 2002. Impact of submerged macrophytes including charophytes on phyto- and zooplankton communities: allelopathy versus other mechanisms. Aquat. Bot., 72, 261-274.

Weitzel R.L., 1979. Periphyton Measurements and Applications. In: Weitzel R.L. (ed.), Methods and measurements of periphyton communities: a review, American society for testing and materials, Baltimore, 3-33.

Žuna Pfeiffer T., Mihaljević M., Stević F. and Špoljarić D., 2013. Periphytic algae colonization driven by variable environmental components in a temperate floodplain lake. Ann. Limnol. - Int. J. Lim., 49, 179-190.

Cite this article as: T. Žuna Pfeiffer, M. Mihaljević, D. Špoljarić, F. Stević, A. Plenković-Moraj, 2015. The disturbance-driven changes of periphytic algal communities in a Danubian floodplain lake. Knowledge and Management of Aquatic Ecosystems, 416, 02. 